\title{
The ultimate cost of carbon
}

\section{David Archer ${ }^{1}$ (D) Edwin Kite ${ }^{1} \cdot$ Greg Lusk $^{2,3}$}

Received: 16 March 2018 / Accepted: 2 July 2020/ Published online: 15 July 2020

(C) The Author(s) 2020

\begin{abstract}
We estimate the potential ultimate cost of fossil-fuel carbon to a long-lived human population over a one million-year time scale. We assume that this hypothetical population is technologically stationary and agriculturally based, and estimate climate impacts as fractional decreases in economic activity, potentially amplified by a human population response to a diminished human carrying capacity. Monetary costs are converted to units of present-day dollars by multiplying the future damage fractions by the present-day global world production, and integrated through time with no loss due from timepreference discounting. Ultimate costs of $\mathrm{C}$ range from $\$ 10 \mathrm{k}$ to $\$ 750 \mathrm{k}$ per ton for various assumptions about the magnitude and longevity of economic impacts, with a bestestimate value of about $\$ 100 \mathrm{k}$ per ton of $\mathrm{C}$. Most of the uncertainty arises from the economic parameters of the model and, among the geophysical parameters, from the climate sensitivity. We argue that the ultimate cost of carbon is a first approximation of our potential culpability to future generations for our fossil energy use, expressed in units that are relevant to us.
\end{abstract}

Keywords Climate impact · Carbon cycle $\cdot$ Deep future $\cdot$ Cost of carbon

\section{Introduction}

The social cost of carbon (SCC) is a concept that was formulated to account for climate change in cost-benefit analysis (Nordhaus 1982, Pearce 2003, Stern 2006, Greenstone et al. 2013, National Academies of Sciences 2017. Costs from climate change are imposed on models of

Electronic supplementary material The online version of this article (https://doi.org/10.1007/s10584-02002785-4) contains supplementary material, which is available to authorized users.

David Archer

d-archer@uchicago.edu

1 Department of the Geophysical Sciences, University of Chicago, Chicago, IL, USA

2 Department of Philosophy, University of Chicago, Chicago, IL, USA

3 Lyman Briggs College, Michigan State University, East Lansing, MI, USA 
the human economy, assessed relative to a control case without climate change. The presentday value of future costs is obtained by discounting (Ramsey 1928). For emissions in 2010 and discount rates of $2-5 \%$, the $\mathrm{SCC}$ is estimated to be about $\$ 20-50$ per ton of $\mathrm{CO}_{2}(\$ 70-180$ per ton of C) although higher values have been proposed (Ackerman and Stanton 2012, Kopp and Mignone 2012, Greenstone et al. 2013, Moyer et al. 2014, Moore and Diaz 2015, Nordhaus 2017).

Because future damages are discounted to calculate their present-day values, costs that accrue more than a few centuries into the future become negligible to the present. However, the time scales of the carbon cycle, sea level change, and soil responses to present emissions are much longer than this and are mostly missed by the SCC (National Academies of Sciences 2017). This paper formulates and estimates an ultimate cost of carbon (UCC), integrated over the entire geophysical response to the human climate perturbation. The formulations of the UCC and the SCC are contrasted in Table 1. The two metrics are based on irreconcilably different assumptions, and apply over different time frames, and are therefore not simply or directly comparable.

\section{Methods}

\subsection{Model formulation}

It is impossible to predict the deep future of humanity, so our formulation leaves out any consideration of human technological development. The UCC is based on climate impacts to a hypothetical human population that is technologically stationary, agrarian, and in steady state with the carrying capacity of the planet. This unrealistic formulation is not a prediction, but a necessary idealization that makes the problem tractable to address, and the result easy to visualize.

Table 1 Comparison of the social and ultimate costs of carbon

\begin{tabular}{|c|c|c|}
\hline & Social cost of carbon (SCC) & Ultimate cost of carbon (UCC) \\
\hline Goal & $\begin{array}{l}\text { Present-day net value of present and future } \\
\text { costs, which are discounted due to assumed } \\
\text { future growth and preference for } \\
\text { present-day welfare }\end{array}$ & $\begin{array}{l}\text { Equivalent value of cumulative future costs, in } \\
\text { present-day units, based on extrusion of our } \\
\text { present-day world into the indefinite future. } \\
\text { With no growth, the discount rate }=0 \% \text {. }\end{array}$ \\
\hline $\begin{array}{l}\text { Characteristic } \\
\text { time scale }\end{array}$ & 30 years, set by discount rate & $\begin{array}{l}10 \text { to } 200 \mathrm{kyr} \text {, set by landscape processes or the } \\
\text { geological carbon cycle }\end{array}$ \\
\hline $\begin{array}{l}\text { Economic } \\
\text { model }\end{array}$ & $\begin{array}{l}\text { Extrapolated labor and predicted capital are } \\
\text { combined using a specified or predicted } \\
\text { productivity coefficient }\end{array}$ & $\begin{array}{l}\text { Human activity, population, and economy are } \\
\text { equal to present day, scaled by decreases in } \\
\text { the planetary carrying capacity }\end{array}$ \\
\hline Climate costs & $\begin{array}{l}\text { Fractional decrease in economic production } \\
\text { relative to a no-warming control }\end{array}$ & same \\
\hline $\begin{array}{l}\text { Utility } \\
\text { function }\end{array}$ & $\begin{array}{l}\text { Average (per capita), taken as the log of } \\
\text { consumption (GWP/cap). } \\
\text { Near-future population changes are usually } \\
\text { specified or strongly influenced by inertia } \\
\text { of the present day. }\end{array}$ & $\begin{array}{l}\text { Total utility (GWP). Costs accrue linearly, } \\
\text { in units of present-day dollars, rather than } \\
\text { logarithmically. Human population in the } \\
\text { distant future is determined by steady-state } \\
\text { carrying capacity. }\end{array}$ \\
\hline Cost basis & $\begin{array}{l}\text { Marginal cost of emitting one additional ton of } \\
\mathrm{C} \text {, given what has already been emitted }\end{array}$ & $\begin{array}{l}\text { Average cost of all carbon ever emitted } \\
\text { (total cost/cumulative emission) }\end{array}$ \\
\hline Value, \$/ton C & Typically $<\$ 100$ & $\$ 10,000-\$ 600,000$ \\
\hline
\end{tabular}




\subsection{Economic formulation}

Climate damages in the model are cast in the form of a fractional decrease of economic activity between a warming case and a no-warming control. The control case is assumed to have a steady, persistent economic productivity equal to the present-day gross world production (GWP) of $\$ 100$ trillion/year. Future fractional changes in human activity are multiplied by the present-day GWP to tabulate costs in units of present-day dollars.

If in an alternate scenario the GWP were to grow before plateauing at, for example, a higher steady GWP than we have today, the actual dollar cost from climate damages would be higher than we calculate. A UCC defined in actual dollars, including growth, would be impossible to constrain, because the long-term economic and technological future of humanity is impossible to reliably predict, and it is beyond the scope of this paper to try. In our formulation, scaling future damage fractions by present-day GWP, we are valuing the fractional climate damages to future generations as though they applied to our own world: valuing the existence of future generations, rich or poor, as much as we value ours. Normalizing to present-day GWP puts the result in units of present-day dollars, making it easy to visualize.

Uncertainty in future growth undermines the use of the UCC in any calculation of optimality. Comparing it with the SCC or costs of mitigation also requires relating costs through deep time, which remains a question for economics, futurology, and moral philosophy, and is also beyond the scope of this paper. The UCC is cast in units of present-day dollars, but it cannot be taken to the bank, exactly. It is a scale bar for climate damages, presented in modern-day terms.

It seems likely that the dominant impact of our fossil fuel use on the world and human activity 100,000 years from now will be through persistent changes in climate, rather than by our fossil-fuel-based construction of some long-lived economic infrastructure or persistent wealth. If this is the case, the UCC can be seen as a first approximation of our potential culpability to future generations, expressed in units that are meaningful to us.

The costs are accrued linearly, even though the welfare benefit of consumption is typically treated as logarithmic (for example, Golosov et al. 2014), for clarity and because the economies of the hypothetical worlds differ by order tens of percent, a relative range over which the $\log$ function is approximately linear. The scaled costs from all future years are accumulated through time, with no loss due to discounting, analogously to how one would time-integrate a $\mathrm{CO}_{2}$ source to get cumulative emissions that drive climate change. In the exponentially growing world of economics and finance, relating value across time requires consideration of how future values should be discounted. The discount rate, $r$, used to calculate the presentday value of a future cost (Ramsey 1928), is calculated as

$$
r=\delta+\eta g
$$

where $\delta$ is a pure rate of time preference (concern for the future vs. eating dessert first), $g$ is the growth rate of per capita income, and $\eta$ is the elasticity of the marginal utility of consumption (expressing the different impacts of giving an extra dollar to a rich versus a poor person). The pure time preference may be larger than $0 \%$ to reflect a selfish interest in the present day, but to express a particular ethical position, or if we assume that the representative individuals in the scenario live forever, $\delta$ might be set to $0 \%$ (Stern 2006).

The growth term $(\eta g)$ expresses the idea that a cost, fixed in dollars, would be relatively smaller in a wealthier future. In the formulation for the UCC, the assumption of steady state 
requires that the growth rate $g=0 \%$ under conditions of constant planetary habitability. Under these idealized conditions, values are combined through time using a discount rate $r$ equal to $0 \%$.

In addition to direct climate impacts on the economy due to impacts on worker productivity, storm damage, etc. (Weitzman 2009, Howard and Sterner 2017, Hsiang et al. 2017, National Academies of Sciences 2017, Burke et al. 2018), in the long-term steady state, there is a potential population feedback that could impact the scale of the human enterprise. In economic models of climate change, GDP does not respond strongly to changes in agricultural land (Nordhaus 2017). On the longer time scales of the UCC, a steady-state population declines by definition in response to a decrease in Earth's carrying capacity or agricultural potential, just as wildlife populations are declining now, in response to decreasing undisturbed range. This might not affect the well-being of individuals (GWP per capita), but its impact on the total utility (GWP) counts as a cost in the UCC. From the perspective of people living in the nowarming control case, the loss of some fraction of their world would seem costly, as it would to us if we were to sacrifice some fraction of our world today. Decreasing the scale of a future human population would increase their risk of extinction and decrease their scope for creativity (Parfit 2017).

\subsection{Biophysical formulation}

The analysis in this paper is based on a simple numerical model, coded in python, of temperature, sea level, and economic response to global warming (see supplemental materials). In order to capture the entire climate perturbation until the eventual natural uptake of the fossil fuel carbon, the model is run one million years into the future (Walker and Kasting 1992, Archer et al. 1997, Archer 2005, Archer and Brovkin 2008, Archer et al. 2009, Eby et al. 2009, Clark et al. 2016).

\subsubsection{Evolution of atmospheric $\mathrm{CO}_{2}$}

The scenario begins with the instantaneous release of 1000-5000 Gton C to the atmosphere. The high end of this range is commonly taken as complete fossil fuel utilization (Sundquist 1985; Archer et al. 1997; Caldeira and Wickett 2005). Most of the available fossil carbon is in the form of coal, the extractable inventory of which has at least a factor of three uncertainties (Rogner 1997; Rutledge 2011; Ritchie and Dowlatabadi 2017). Business as usual projections, without mitigation, result in the release of about 1300 Gton $C$ by the year 2100 , with an additional few centuries required to emit the full $5000 \mathrm{Gton} \mathrm{C}$. The model does not attempt to resolve the dynamics of the $\mathrm{CO}_{2}$ release and equilibration with the ocean, on time scales of decades to centuries, because the costs accruing on these time scales are negligible compared with those accruing over millions of years. The first parameter in the model is the amount of $\mathrm{CO}_{2}$ release (Table 2).

Natural carbon-cycle feedbacks may amplify or ameliorate the anthropogenic carbon release. The land surface biosphere has been taking up anthropogenic $\mathrm{CO}_{2}$ (Tans 2009), for reasons that are not well known but might be a response to a longer growing season, or fertilization due to the rise in atmospheric $\mathrm{CO}_{2}$ or nitrate deposition. However, a dominant response looking forward is a release of carbon from the decomposition of thawing permafrost soils, which contain thousands of gigatons of C (Lawrence and Slater 2005, Zimov et al. 
Table 2 Parameters to the geophysical component of the model

\begin{tabular}{|c|c|c|}
\hline Parameter name & Description & Value note \\
\hline CReleaseGton & Gigatons of anthropogenic carbon & $\begin{array}{l}\text { The buffer chemistry in the model is intended for the } \\
\text { range } 1000-5000 \text { Gton } C\end{array}$ \\
\hline CFeedbackFactor & $\begin{array}{l}\text { Fraction by which the natural carbon } \\
\text { cycle amplifies the human source }\end{array}$ & $\begin{array}{l}\text { Presumably }<1.5 \text {, or else the natural carbon cycle } \\
\text { would be observably tippier } \\
\text { (Archer and Buffett 2005) }\end{array}$ \\
\hline oceanAcidTime & $\begin{array}{l}\text { Time scale for } \mathrm{pH} \text { recovery of the } \\
\text { ocean, years }\end{array}$ & $\begin{array}{l}\text { Probably a few thousand years } \\
\quad \text { (Broecker and Peng 1987) (Archer et al. 1997) }\end{array}$ \\
\hline thermostatTime & $\begin{array}{l}\text { Time scale for atmospheric } \mathrm{CO}_{2} \\
\text { recovery, years }\end{array}$ & $\begin{array}{c}\text { About } 200 \mathrm{kyr} \text { from models (Berner 2006), probably } \\
\text { longer than the 100-kyr glacial interglacial cycles }\end{array}$ \\
\hline warmingTime & $\begin{array}{l}\text { Time scale for temperature } \\
\text { equilibration }\end{array}$ & $\begin{array}{l}\text { Governed by ocean circulation, in reality a range of } \\
\text { time scales up to about } 1000 \text { years } \\
\text { (Bala et al. 2005). }\end{array}$ \\
\hline iceMeltingTime & $\begin{array}{l}\text { Time scale for collapsing ice sheets, } \\
\text { years }\end{array}$ & $\begin{array}{l}\text { Models find time scales of a few thousand years } \\
\text { (Clark et al. 2016), but could be centuries } \\
\text { (Hansen et al. 2016) }\end{array}$ \\
\hline $\mathrm{dt} 2 \mathrm{X}$ & $\begin{array}{l}\text { The equilibrium climate sensitivity, } \\
\text { degrees } \mathrm{C} \text { per doubling of } \mathrm{CO}_{2}\end{array}$ & $\begin{array}{l}\text { Range from IPCC Fifth Assessment Report is } \\
1.5-4.5^{\circ} \mathrm{C} \text { (IPCC 2014) }\end{array}$ \\
\hline
\end{tabular}

2009). The lack of runaway carbon greenhouses in the paleoclimate record suggests the magnitude of this feedback is probably less than 1.5 (Archer and Buffett 2005).

The $\mathrm{CO}_{2}$ perturbation relaxes back to zero on two time scales, representing different stages of the response. First, on a shorter time scale, acidification of the ocean drives an imbalance in the weathering and burial of $\mathrm{CaCO}_{3}$, which ultimately restores the $\mathrm{pH}$ of the ocean (Broecker and Peng 1987; Archer et al. 1997; Caldeira and Wickett 2005), replenishing its buffer capacity to absorb $\mathrm{CO}_{2}$. Second, a longer time scale, the excess $\mathrm{CO}_{2}$ from the surface "fast" carbon cycle (atmosphere, ocean, land surface) is removed by enhanced weathering of calcium-bearing igneous rocks (Berner 2006), which carry $\mathrm{CO}_{2}$ back to the deep Earth as $\mathrm{CaCO}_{3}$. This process is known as the rock weathering "thermostat." Each exponential decay is parameterized by an initial "airborne" component of the released $\mathrm{CO}_{2}$ (residing in the atmosphere), and a time scale, as

$$
C_{\text {Atm }}=C_{\text {AtmInit }}+C_{\text {Release }}\left(A_{\text {OcnEquil }} e^{-\lambda_{\text {Acid }} t}+A_{\text {Neut }} e^{-\lambda_{\text {Thermostat }} t}\right)
$$

where $C$ denotes a mass of carbon in gigatons as $\mathrm{CO}_{2}, A$ an initial airborne fraction, and $\lambda$ a time scale in years. The airborne fractions, $A_{\mathrm{OcnEquil}}$ and $A_{\mathrm{Neut}}$, are taken from the carbon cycle model results from the "long tail" model intercomparison project (Archer et al. 2009) (Fig. 1). The airborne fraction values from the models at 1000 years are taken to be representative of the stage in which the ocean is acidified, after $\mathrm{CO}_{2}$ invasion but mostly before $\mathrm{CaCO}_{3}$ dissolution neutralizes the acidity of the fossil $\mathrm{CO}_{2}$. The airborne fractions at 10,000 years are taken to represent neutralized ocean conditions, which will subside on the rock weathering "thermostat" time scale. The simulations show higher airborne fractions for 5000-Gton C release experiments than for 1000 Gton $\mathrm{C}$, due to exhaustion of the buffer chemistry of the ocean before its restoration by $\mathrm{CaCO}_{3}$ compensation. For release between 1000 and 5000 (for marginal cost estimation), the airborne fraction values are interpolated.

The time scale for ocean $\mathrm{pH}$ neutralization has been estimated to range between 1000 and 10,000 years (Broecker and Peng 1987; Archer et al. 1997; Archer et al. 1998; Caldeira and Wickett 2005). The decrease in the ocean concentration of carbonate ion $\left(\mathrm{CO}_{3}{ }^{2-}\right)$ causes a 

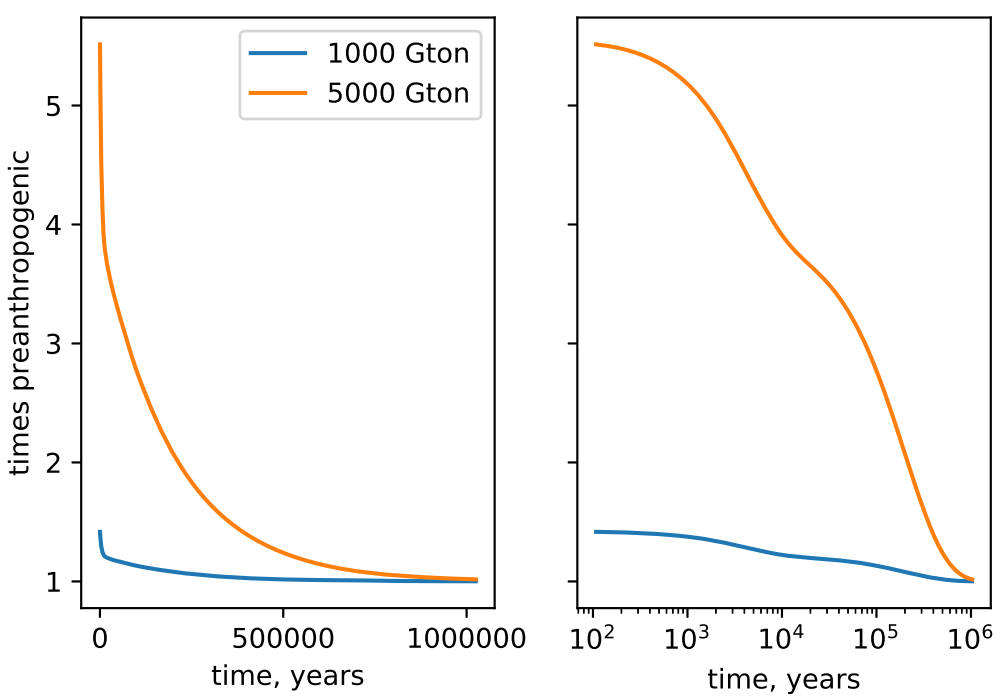

Fig. 1 Atmospheric $\mathrm{CO}_{2}$ evolution in the model. Results from 1000 and 5000 Gton $\mathrm{C}$ anthropogenic $\mathrm{CO}_{2}$ releases are plotted on a linear time scale on the left, and a log scale on the right

decrease in $\mathrm{CaCO}_{3}$ production (Riebesell et al. 2000), and an increase in sedimentary $\mathrm{CaCO}_{3}$ dissolution (Archer et al. 1998), while the increase in atmospheric $\mathrm{CO}_{2}$ and the increase in temperature lead to an increase in terrestrial $\mathrm{CaCO}_{3}$ weathering (Liu et al. 2018), all of which contribute to the neutralization response. The ocean $\mathrm{pH}$ evolution through the glacial cycles serves as a constraint on this response time, but it is complicated by a significant deglacial increase in shallow-water $\mathrm{CaCO}_{3}$ deposition on flooding continental shelves (Milliman 1993).

The time scale for ultimate $\mathrm{CO}_{2}$ removal by the weathering thermostat is set by the rates of geochemical weathering reactions, combining a $\mathrm{CaO}$ component of igneous rocks with $\mathrm{CO}_{2}$ to produce $\mathrm{CaCO}_{3}$, the pathway for carbon return to the deep Earth. These reactions, balanced against natural $\mathrm{CO}_{2}$ degassing from the Earth, comprise a planetary carbon cycle thermostat system (Walker et al. 1981, Berner et al. 1983). The time constant for reaching the equilibrium $\mathrm{CO}_{2}$ concentration is estimated from the Geocyc model (Archer et al. 2009, http://climatemodels.uchicago.edu/geocyc/, based on Berner et al. 1983) to be about 200 ,000 years.

The weathering thermostat time scale is informed by reconstructions of the past. The Paleocene-Eocene thermal maximum event can be taken as an analog to global warming, with a fast release of isotopically light carbon, a resulting climate warming, and a gradual recovery. The event as recorded in ocean sediments has a smooth exponential recovery with a time scale of $\sim 100,000$ years (Zachos et al. 2001). The more recent glacial cycles included large swings in atmospheric $\mathrm{CO}_{2}$, the 100-kyr durations of which set a lower limit to the response time, consistent with our best estimate of a 200-kyr response time.

The anthropogenic impact on climate will take place within the context of natural climate variability, driven through glacial/interglacial cycles resulting, in part, from wobbles in Earth's orbit around the sun. However, Earth's orbit around the sun is currently approaching circularity, as it does every $400 \mathrm{kyr}$, minimizing variations in sunlight intensity and leading to an expected long interglacial interval like Marine Ice Sheet Stage 11 about 400 kyr ago (Paillard 2001). The rhythm of the ice ages complicates the impact of global warming, but less so than if we had started industrial activity $200 \mathrm{kyr}$ ago when orbital variations in sunlight intensity were 
more intense (Archer and Ganapolski 2005). It would no doubt be costly to descend into another ice age, but if this was a motivating factor in fossil energy use, our carbon stock could be deployed more strategically by waiting until the descent into an ice age is imminent (Shaffer 2009).

In summary, the carbon drawdown dynamics are idealized but well understood relative to other parts of this analysis. Atmospheric $\mathrm{pCO}_{2}$ values are plotted as a function of time in Fig. 1.

\subsubsection{Global mean temperature anomaly}

The equilibrium temperature for a given atmospheric $\mathrm{CO}_{2}$ concentration is calculated from the climate sensitivity as

$$
T_{\text {equil }}=\Delta T_{2 x} \times \frac{\ln \left(\frac{p C O_{2}}{p C O_{\text {init }}}\right)}{\ln (2)}
$$

where $\Delta T_{2 x}$ is a parameter in the model and is thought to be in the range of $1.5-4.5^{\circ} \mathrm{C}$ for doubling $\mathrm{CO}_{2}$ (IPCC 2014).

The temperature of the Earth relaxes toward $T_{\text {equil }}$ on a time scale specified as a model parameter, warmingTime. The initial $T_{\text {evolving }}$ is taken to be $80 \%$ of the initial $T_{\text {equil }}$ value, as an approximation to the present day, and it relaxes toward $T_{\text {equil }}$ as

$$
\Delta T_{\text {evolving }}=\left(T_{\text {equil }}-T_{\text {evolving }}\right) \times \frac{\Delta t}{\text { warming Time }}
$$

After the initial temperature transient, $T_{\text {evolving }}$ is taken as equal to $T_{\text {equil }}$ as a numerically stable approximation. The evolution of temperature for the two values of $\mathrm{CO}_{2}$ releases is shown in Fig. 2.
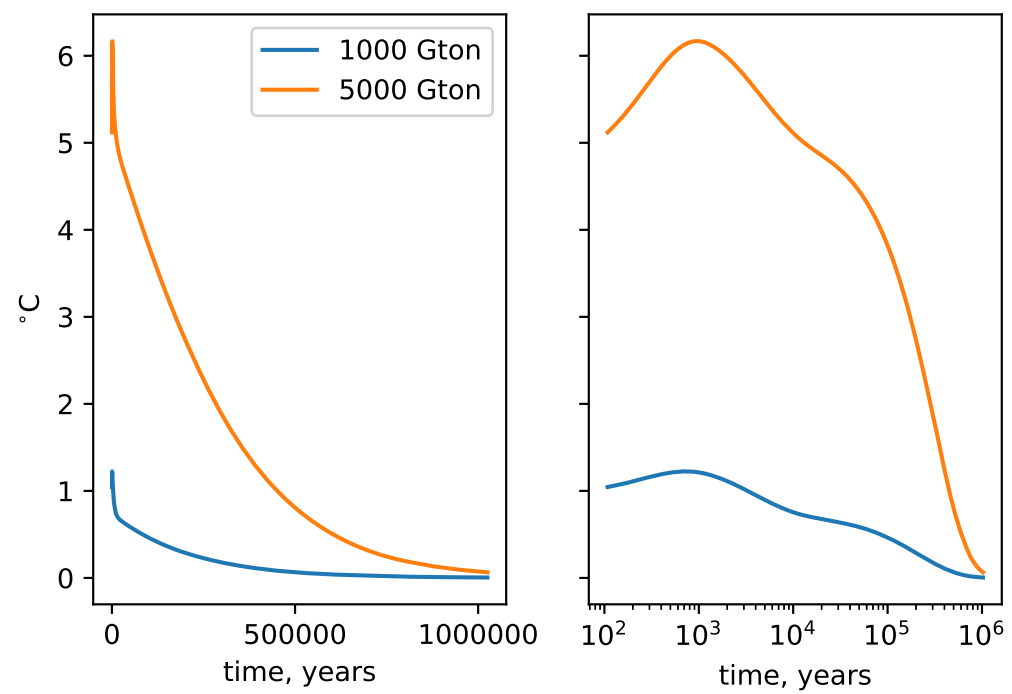

Fig. 2 Model global temperature anomalies from releases of 1000 and 5000 Gton C 


\subsubsection{Sea level}

The time scale for the ice sheet response is thought to be a few millennia, based on ice sheet modeling (Alley et al. 2005) and the general time scale of sea level change recorded in oxygen isotopic composition of ice cores (Hays et al. 1976). However, past intervals of sea level rise have been faster than this, including the Heinrich events (Broecker et al. 1992) and deglaciation (Fairbanks 1989). A positive feedback between ice sheet melting, meltwater, and ocean stratification has been proposed to explain the fast sea level rise events of the past, suggesting a potential sea level rise time scale of centuries, rather than millennia, in our future (Hansen et al. 2016). Also, a real ice sheet grows until it melts at its base, at which point it collapses rapidly (Macayeal 1993; Paillard 1998). The simple exponential-relaxation-to-equilibrium sea level model used here is simpler than we expect from reality, and if anything conservative in response time and possible tipping behavior.

Ultimate sea level rise in the model (Fig. 3) is driven by the temperature anomaly, based on observed covariation of sea level and global temperature from paleoclimate reconstructions (Archer and Brovkin 2008). The forecast for the year 2100 is for about $1 \mathrm{~m}$ of sea level rise (Rahmstorf 2007, Kopp et al. 2017), but a full climate/ice sheet model run for thousands of years found sea level rise of $50 \mathrm{~m}$ (Alley et al. 2005; Clark et al. 2016). The discrepancy is due to timing, in that ice sheets will presumably not have time to equilibrate by the year 2100 .

The ice sheets in the model recover on the time scale of the ultimate $\mathrm{CO}_{2}$ drawdown by the weathering thermostat. This simple one-way forcing $\left(\mathrm{CO}_{2}\right.$ drives ice) is an idealization and neglects whatever mechanism or (more likely) mechanisms (Archer et al. 2000, Ganopolski and Brovkin 2017) were at work through the glacial cycles, when changes in orbital forcing and ice sheet dynamics drove a feedback atmospheric $\mathrm{CO}_{2}$ response. Because atmospheric $\mathrm{CO}_{2}$ is driven by human sources today, it would be speculative to predict how the natural $\mathrm{CO}_{2}$ ice sheet deglaciation feedback might operate in the future.
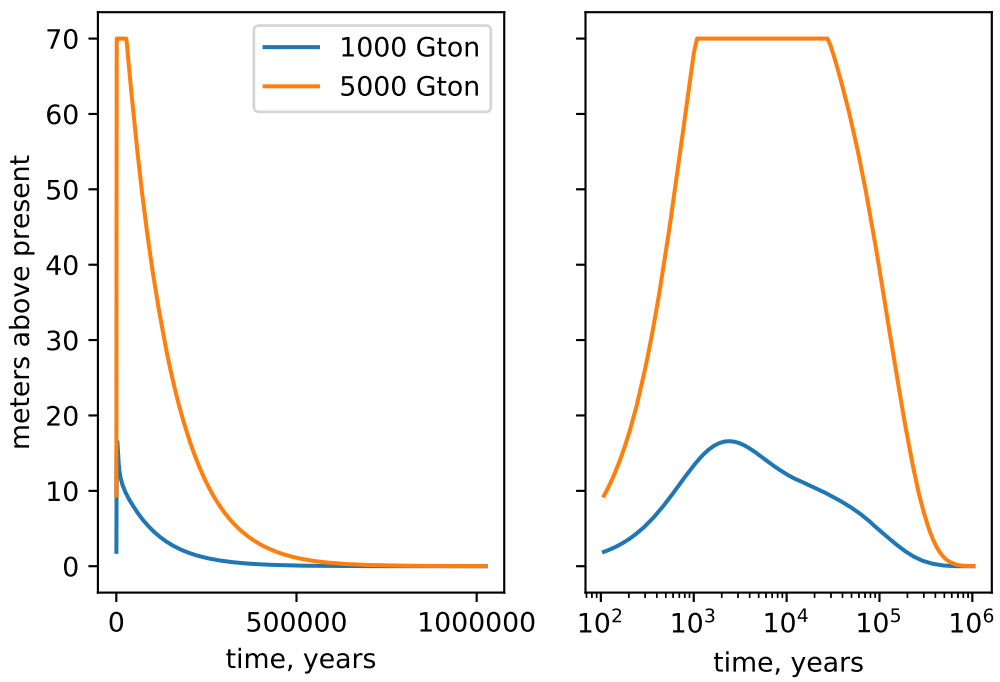

Fig. 3 Sea level responses of the model 


\subsection{Impacts}

In our formulation, costs accrue due to two factors: directly due to an altered climate and due to sea level rise. Both are calculated based on coefficients in $\% \mathrm{GWP} /{ }^{\circ} \mathrm{C}$ and $\% \mathrm{GWP} / \mathrm{meter}$ (Table 3).

\subsubsection{Costs due to climate}

Economics models have been used to predict the impact of warming on the economic productivity of the near future. From the perspective of deep time, this scenario consists of a short-term impact of a sudden shift in climate on an existing population and infrastructure. Remembering that our formulation is an idealization in which technological innovation is not allowed, we project these global costs forward into the deep future as a provisional starting point.

For relatively conservative temperature changes of $3{ }^{\circ} \mathrm{C}$, the models that are used in SCC calculations predict $0-1 \% /{ }^{\circ} \mathrm{C}$ (Greenstone et al. 2013). Studies cited in the IPCC scientific assessments, for temperature changes of $2.5{ }^{\circ} \mathrm{C}$, had mean values of about $0.6 \% /{ }^{\circ} \mathrm{C}$ ( Tol 2016). Values from Burke et al. (2015), for $3{ }^{\circ} \mathrm{C}$ of warming, range between 2.6 and $20 \% /{ }^{\circ} \mathrm{C}$. Based on these results, our analysis assumes $1 \% \mathrm{GDP} /{ }^{\circ} \mathrm{C}$ in damages directly from climate change. The linear dependence of the model will be conservative in that it excludes the possible catastrophic changes at high degrees of warming (Weitzman 2009).

On time scales longer than a few human generation times, we might expect a human population response to changes in agricultural potential. Crop yields decrease significantly at temperatures above $30-34{ }^{\circ} \mathrm{C}$ (Porter et al. 2014), and continental interiors are expected to systematically dry in a warming world (Byrne and O'Gorman 2015). These constraints suggest that the agricultural capacity of a $3{ }^{\circ} \mathrm{C}$ warmer world could be decreased by $10 \%$ relative to the no-warming control case (Hsiang et al. 2017), or about $3 \% /{ }^{\circ} \mathrm{C}$.

\subsubsection{Costs due to sea level rise}

The long-term costs of sea level rise become significant if we assume a human population response to the loss of present-day agricultural land.

Figure 4 a shows the cumulative fraction of land area, crop and pasture land, and population as a function of elevation above sea level. These curves were generated from digital gridded density fields for population (SEDAC, NASA, $2.5 \mathrm{~min}$ grid), and crop and pasture land (Ramankutty et al. 2008), interpolated into a gridded field of elevation (ETOPO2, National

Table 3 Parameters to the economic component of the model

\begin{tabular}{lll}
\hline Parameter name & Description & Value note \\
\hline climCostFactor & $\begin{array}{c}\text { Economic penalty due to climate change, } \\
\text { in percent GDP per degree C }\end{array}$ & $1 \% /{ }^{\circ} \mathrm{C}$ is in the range of IAM results \\
seaLevelCostFactor & $\begin{array}{c}\text { Economic penalty due to sea level rise, } \\
\text { in percent GDP for complete melting } \\
(70 \mathrm{~m})\end{array}$ & $\begin{array}{c}15 \% \text { of present-day cropland could be } \\
\text { flooded (Fig. } 4)\end{array}$ \\
econRecoveryTime & $\begin{array}{c}\text { Economic recovery time scale for both types } \\
\text { of cost. }\end{array}$ & $\begin{array}{c}\text { This could be a soil generation time scale of } \\
10 \mathrm{kyr} \text { or a } \mathrm{CO}_{2} \text { thermostat time of } \\
200 \mathrm{kyr}\end{array}$ \\
\hline
\end{tabular}


Geophysical Data Center 2006). The cumulative areal loss of cropland increases more quickly with sea level rise than total land area loss, reflecting higher than average agricultural productivity in low-lying soils, especially fertile river deltas near sea level.

A sea level rise of $70 \mathrm{~m}$ would inundate about $15 \%$ of present-day cropland (and $5 \%$ of pasture land). We postulate that a decrease in agricultural land would translate eventually into a decrease in human population and economic activity, with $70 \mathrm{~m}$ thus reducing GWP by $15 \%$.

\subsubsection{Mechanism and time scale for economic recovery}

A major uncertainty in the model is how long the climate impacts would persist as costs (as per the formulation, in the absence of technology change or adaptation to climate). Both types of costs, due to climate change and sea level rise, might be ameliorated by human migration to higher latitudes. It is possible that some low-latitude regions might become uninhabitable wastelands in a much warmer world (Sherwood and Huber 2010), but there is a lot of currently uninhabited land area in the high latitudes that could be more hospitable to human societies in a warmer world (Fig. 5). A limitation on how quickly humankind could move to high latitudes might arise from the time scales of soil formation, for example, in the Canadian Shield region. If the opening of new landscapes for human habitation compensates for loss of habitability in the topics, then the time scale for economic recovery might be set by the soil formation time scale, rather than that for ultimate $\mathrm{CO}_{2}$ drawdown.

It has been argued that the abundance and quality of the soil have been a strong determinant in the rise and fall of civilizations through the past 5000 years (Montgomery 2007). Soil is derived from weathering of primary bedrock reacting with water, catalyzed biologically by bacteria, plant roots, and deposit-feeding animals. The rate of production of soil is slow by human standards; accumulation rates of a few centimeters per century or less are common,
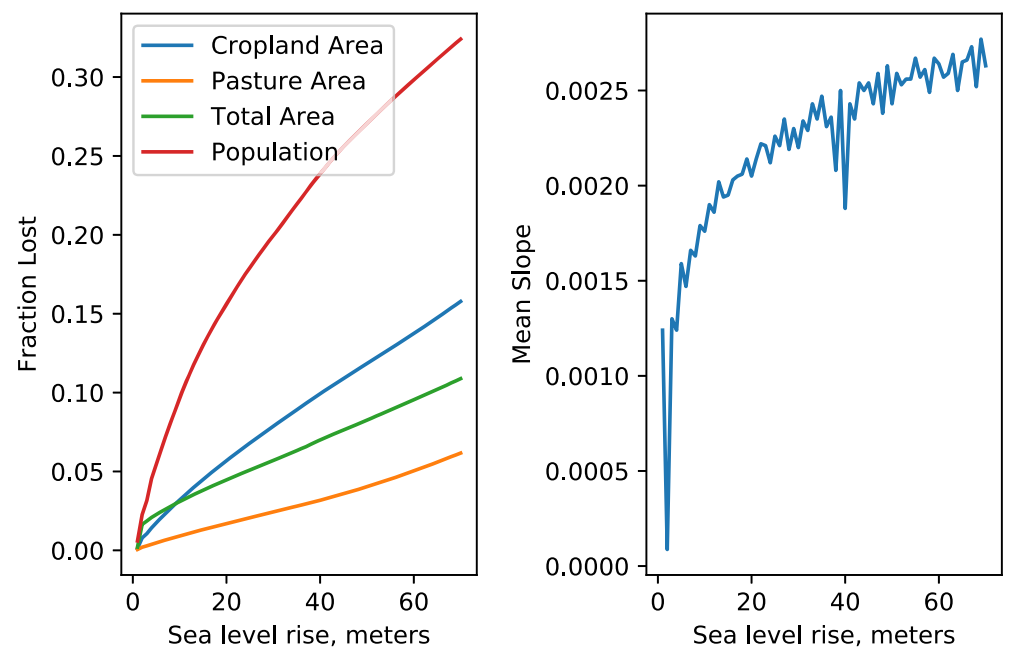

Fig. 4 a Cumulative area fractions lost of present-day land surface, cropland, pasture land, and population, as a function of sea level rise. Generated from digital gridded density fields for population (SEDAC, NASA, 2.5-min grid), and crop and pasture land (Ramankutty et al. 2008), interpolated into a gridded field of elevation (ETOPO2, National Geophysical Data Center, 2006). b Mean land surface slope as a function of elevation above present-day sea level (ETOPO2, National Geophysical Data Center, 2006) 


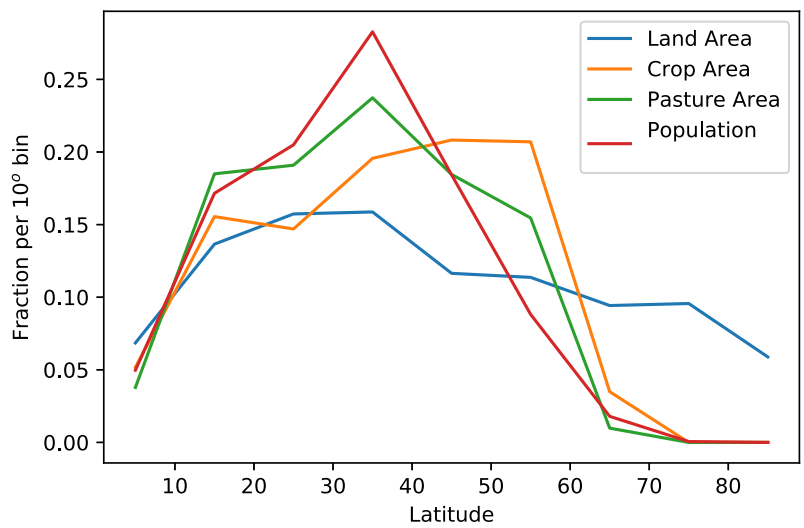

Fig. 5 The distribution of land surface area, croplands, pasture lands, and population as a function of latitude (data from SEDAC, NASA, 2.5-min grid and Ramankutty et al. 2008)

resulting in an overall soil formation time scale that might be of order $10 \mathrm{kyr}$ (Minasny and McBratney 2001).

On time scales of 10 to 100 millennia, the global soil reservoir will have time to evolve through a series of steady states where soil loss must be balanced by soil production. The impact of human soil stewardship will be a primary driver, but it is impossible to predict, so we are left to consider long-term changes in the potential of the land surface to create new soil. This might be affected by the changes in climate (in particular the drying of continental interiors) and by the change in the landscape due to sea level rise. Soil naturally travels downslope, accumulating in flat lowland valleys. Figure 6 shows the average landscape grade derived from ETOPO2 plotted as a function of the elevation above sea level. The average grade at an elevation of $50 \mathrm{~m}$ is twice as steep on average as it is a sea level. The sediment transport in riverine flow that currently deposits in low-lying river deltas (at 50-m elevation or less) would be lost to the ocean in a higher sea level world. This effect would subside as flooded valleys become filled with sediment, as is happening today after deglacial sea level rise in, for example, Chesapeake Bay, on a time scale of up to tens of thousands of years.

Leaving unresolved the question of whether the pace of economic recovery will be set by the time scales of soil development or ultimate carbon cycle, our analysis posits a range of possibilities from 10 to $200 \mathrm{kyr}$ (Table 4).

\subsection{Sensitivity analysis}

Uncertainty ranges for the parameters are estimated in Table 5 and propagated to cost estimates using a Monte Carlo method (Suppl. Fig. 1). The model is run, varying one parameter at a time, with log-uniform probability across a specified range, holding all other parameter values unvarying at the mean between their minimum and maximum values. Then the model is run varying all parameters simultaneously but independently, first for just the geophysical parameters, then for all parameters, economic and geophysical. The total amount of $\mathrm{C}$ emitted is varied along with the rest of the parameters, through a range of 1000-5000 Gton C, but the results are normalized into units of $\$ /$ Gton $\mathrm{C}$ for all statistical treatment. Increasing the number of realizations beyond 10,000 has only a small impact on the results. 

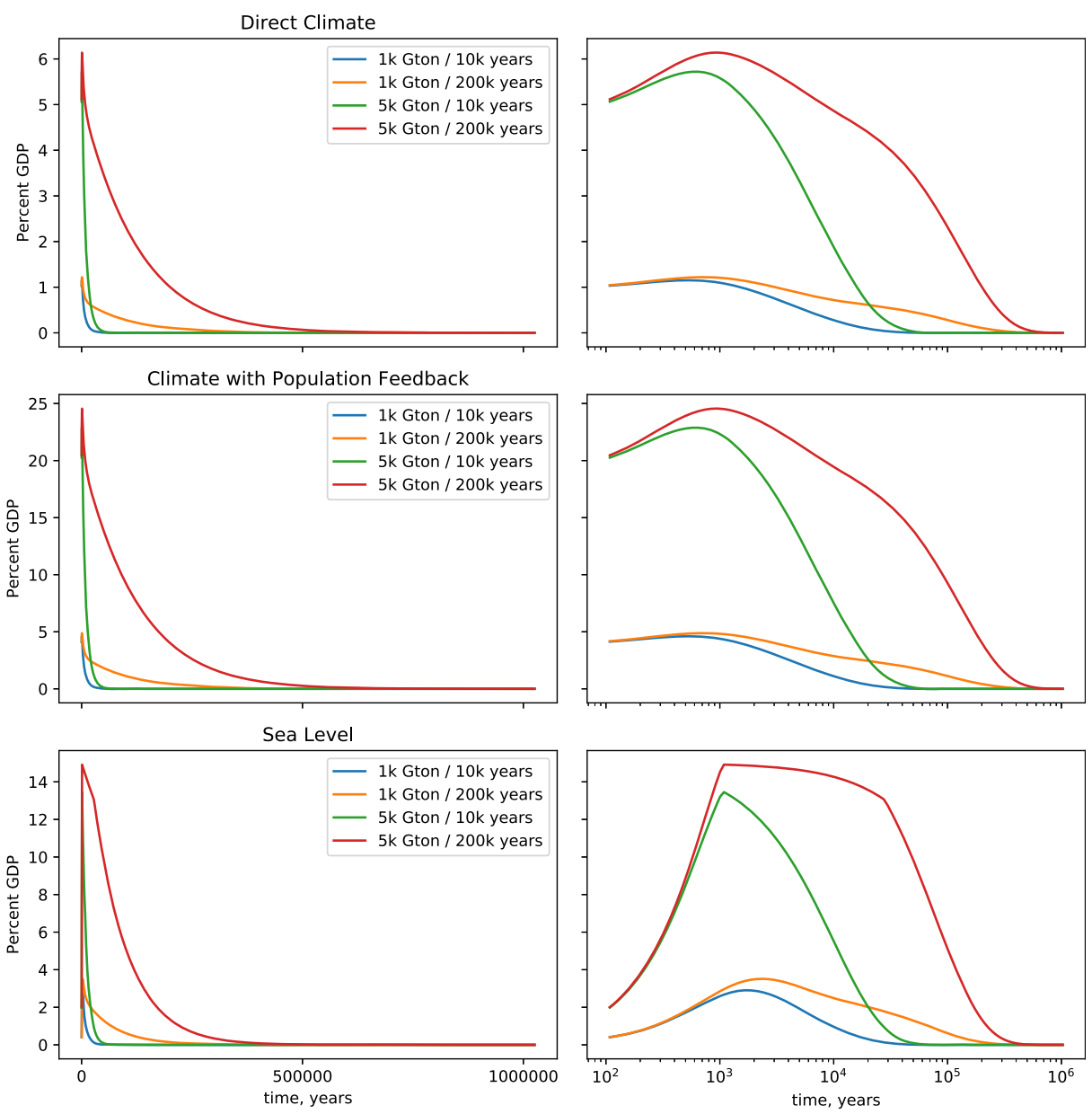

Fig. 6 The time trajectory of economic costs from the model

\section{Results}

Projected costs are plotted in Fig. 6 and summarized in Table 4, for two values of the carbon release magnitude (1000 and 5000 Gton C) and two values of the time scale for economic recovery $(10,000$

Table 4 Costs, in $\$ 1000 /$ ton $\mathrm{C}$

Carbon release, Gton C Recovery time scale, years Direct climate cost Costs assuming a population feedback

\begin{tabular}{llrrrr} 
& & & Climate & Sea level & Total \\
\cline { 3 - 5 } 1000 & $10 \mathrm{kyr}$ & 8.3 & 33.1 & 25.8 & 59.0 \\
& $200 \mathrm{kyr}$ & 75.2 & 301.0 & 180.3 & 481.3 \\
5000 & $10 \mathrm{kyr}$ & 10.2 & 40.8 & 27.5 & 68.3 \\
& $200 \mathrm{kyr}$ & 121.2 & 484.9 & 265.1 & 750.1 \\
\hline
\end{tabular}




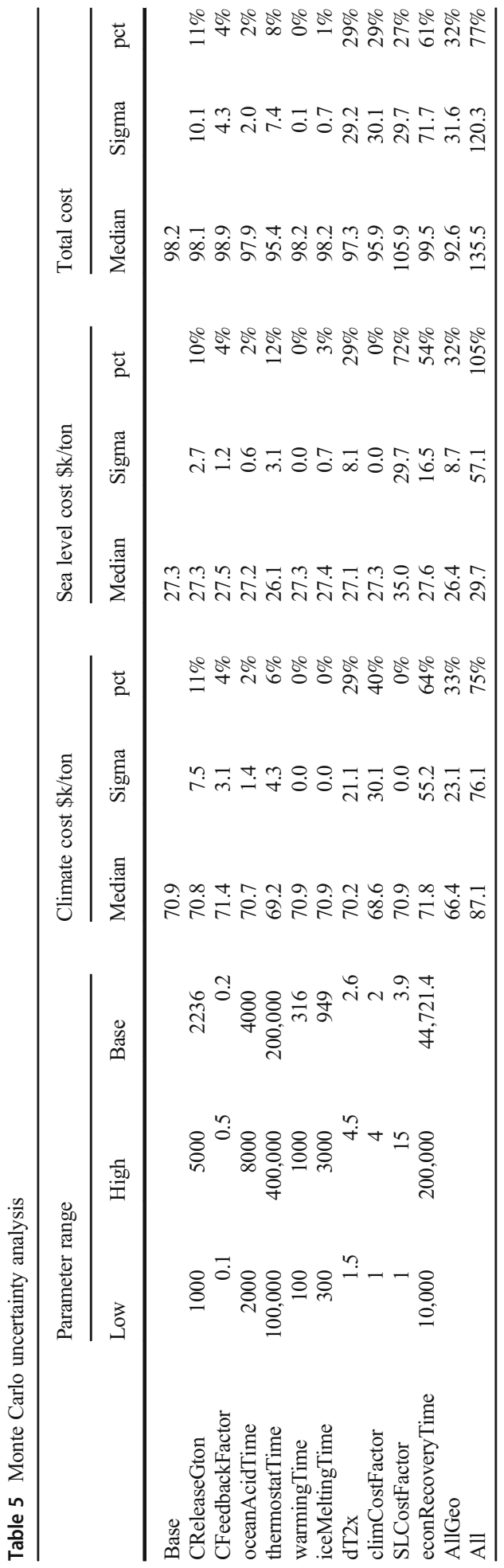


and 200,000 years). The coefficient for direct climate costs is $1 \% \mathrm{GWP} /{ }^{\circ} \mathrm{C}$, while accounting for a human population feedback raises the value to $4 \% /{ }^{\circ} \mathrm{C}$, and that for $70 \mathrm{~m}$ sea level rise to $15 \% \mathrm{GWP}$.

The costs per ton $\mathrm{C}$ are relatively similar between 1000 and $5000 \mathrm{Gton} \mathrm{C}$ scenarios, compared with much larger differences between the cases of slow versus fast economic recovery. For direct climate costs only, the total cost is around $\$ 10 \mathrm{k}$ per ton if the recovery rate is set by soil formation in high latitudes, or roundly $\$ 100 \mathrm{k}$ per ton if the economic recovery has to await the ultimate drawdown of $\mathrm{CO}_{2}$. The costs that presume a population feedback come to roundly $\$ 60 \mathrm{k} /$ ton and $\$ 600 \mathrm{k} /$ ton for the fast and slow recovery rates, respectively.

Using the median values of all input parameters, the costs are about $\$ 98 \mathrm{k} /$ ton $\mathrm{C}$. The $1 \sigma$ uncertainty due to the geophysical parameters is about $\$ 34 \mathrm{k}$, and due to geophysical plus economic parameters, about $\$ 116 \mathrm{k}$, with the distribution skewed toward higher costs in all cases. Costs are simply linearly proportional to the cost coefficients, and nearly linearly dependent on the economic recovery time scale (Suppl Fig. 2). Among the geophysical parameters, the climate sensitivity contributes the most overall uncertainty, followed by the amount of carbon released and the time scale for ultimate $\mathrm{CO}_{2}$ drawdown.

\section{Discussion}

The cost of abating our ongoing $\mathrm{CO}_{2}$ emissions has been estimated to be in the range $\$ 10-100$ per ton of $\mathrm{C}$ (Enkvist et al. 2009). Failing that, the cost of chemically removing a ton of $\mathrm{C}$ as $\mathrm{CO}_{2}$ from the atmosphere using industrial chemical engineering methods has been estimated to be $\$ 2200$ (Socolow et al. 2011) or $\$ 360$ (Keith et al. 2018). These estimates are much lower than the ultimate cost of carbon and would be a bargain if the UCC was directly fungible with present-day mitigation costs. However, it might not in the self-interest of any single generation to pay to clean it up, since no single generation would pay the entire ultimate climate costs.

The total cleanup costs would be enormous. A return to a "safe" atmospheric $\mathrm{CO}_{2}$ concentration of $350 \mathrm{ppm}$ (Hansen et al. 2005) within a few decades would require removing about 440 Gton C (using the ISAM carbon cycle/integrated assessment model at http://climatemodels.uchicago. edu/isam/(Cao and Jain 2005)). At a cost of $\$ 360$ per ton of C (Keith et al. 2018), the total cleanup debt today is about $\$ 160$ trillion, about 1.6 years of present-day GWP. The cleanup debt is accumulating at a rate of about $\$ 3.6$ trillion per year, about 3.6\% of GWP.

Humanity could defend some fraction of the inundating land surface using dikes. Based on a contemporary Dutch cost of about $\$ 10 / \mathrm{m}^{3}$ of dam, assuming triple dike walls $60 \mathrm{~m}$ high and $120 \mathrm{~m}$ wide at the base, we calculate a cost of about $\$ 100,000$ per meter of coastline, coming to $\$ 10^{14}(\$ 100$ trillion, 1-year GWP) for the entire million-kilometer coastline of the world. Dividing by the amount of carbon emitted results in a cost of about $\$ 5 /$ ton of $\mathrm{CO}_{2}$ emitted. This effort would ameliorate land loss by sea level rise, but it would obviously not change the impacts of a warmer climate. A downside is that this strategy would commit future generations to ongoing maintenance of the dikes. The almost absurd global scale of the proposal, and its relatively inexpensive price tag, is another demonstration of the massive scale of the ultimate damage from carbon energy.

\section{Conclusions}

This paper presents a formulation for assessing deep-time climate change in units of presentday dollars per ton of carbon. The scope of the definition for such a cost is limited by what is 
tractable, and the result is only valid under particular, idealized circumstances including zero growth or technology change, and human population in steady state with Earth's carrying capacity. The UCC is unrealistic as a forecast for the future, in and of itself, but it is easy to visualize and provides a scale bar for ultimate climate damage in present-day terms.

The UCC in our formulation ranges from $\$ 10 \mathrm{k}$ to $\$ 750 \mathrm{k}$ per ton of $\mathrm{C}$, with a central value about $\$ 100 \mathrm{k}$ per ton. The $1 \sigma$ uncertainty due to geophysical parameters is about $\$ 34 \mathrm{k}$, and due to geophysical plus economic, about $\$ 116 \mathrm{k}$, skewing to higher values in all cases. Among geophysical parameters to the model, the climate sensitivity contributes the most to the uncertainty in the result.

The UCC is not directly comparable with the social cost of carbon, or costs of mitigation, because of fundamental differences in their assumptions and formulations, and the fact that they apply over different time scales. Assuming that the climate impacts from fossil carbon use will persist much longer than any economic infrastructure that we use fossil fuels today to build, the UCC can be seen as a first approximation of our culpability to future generations, expressed in terms that are relevant to us.

Acknowledgments This paper benefitted immensely from comments and suggestions by Soren Anderson, Jim Franke, Philippe Tortelle, Detlef van Vuuren, David Weisbach, and several anonymous reviewers.

Open Access This article is licensed under a Creative Commons Attribution 4.0 International License, which permits use, sharing, adaptation, distribution and reproduction in any medium or format, as long as you give appropriate credit to the original author(s) and the source, provide a link to the Creative Commons licence, and indicate if changes were made. The images or other third party material in this article are included in the article's Creative Commons licence, unless indicated otherwise in a credit line to the material. If material is not included in the article's Creative Commons licence and your intended use is not permitted by statutory regulation or exceeds the permitted use, you will need to obtain permission directly from the copyright holder. To view a copy of this licence, visit http://creativecommons.org/licenses/by/4.0/.

\section{References}

Ackerman F, Stanton EA (2012) Climate risks and carbon prices: revising the social cost of carbon. Economics: The Open-Access, Open-Assessment E-Journal 6:2012-2010

Alley RB, Clark PU, Huybrechts P, Joughin I (2005) Ice-sheet and sea-level changes. Science 310:456-471

Archer D (2005) Fate of fossil-fuel CO2 in geologic time. J Geophys Res Oceans. https://doi.org/10.1029/2004 JC002625

Archer D, Brovkin V (2008) The millennial lifetime of fossil fuel CO2. Clim Chang 90:283-297

Archer D, Buffett B (2005) Time-dependent response of the global ocean clathrate reservoir to climatic and anthropogenic forcing. Geochem Geophys Geosyst 6. https://doi.org/10.1029/2004GC000854

Archer D, Ganapolski A (2005) A movable trigger: fossil fuel CO2 and the onset of the next glacition. Geochem Geophys Geosys 6:Q05003. https://doi.org/10.1029/2004GC000891

Archer D, Kheshgi H, Maier-Riemer E (1997) Multiple timescales for neutralization of fossil fuel CO2. Geophys Res Lett 24:405-408

Archer D, Kheshgi H, Maier-Reimer E (1998) Dynamics of fossil fuel CO2 neutralization by marine CaCO3. Glob Biogeochem Cycles 12:259-276

Archer DE, Winguth A, Lea D, Mahowald N (2000) What caused the glacial / interglacial atmospheric pCO2 cycles? Rev Geophys 38:159-189

Archer DE, Eby M, Brovkin V, Ridgewell AJ, Cao L, Mikolajewicz U, Caldeira K, Matsueda H, Munhoven G, Montenegro A, Tokos K (2009) Atmospheric lifetime of fossil fuel carbon dioxide. Ann Reviews Earth Planet Sci 37:117-134

Bala G, Caldeira K, Mirin A, Wickett M, Delira C (2005) Multicentury changes to the global climate and carbon cycle: results from a coupled climate and carbon cycle model. J Clim 18:4531-4544 
Berner RA (2006) GEOCARBSULF: a combined model for Phanerozoic atmospheric O-2 and CO2. Geochim Cosmochim Acta 70(23):5653-5664

Berner RA, Lasaga AC, Garrels RM (1983) The carbonate-silicate geochemical cycle and its effect on atmospheric carbon dioxide over the past 100 million years. Am J Sci 283:641-683

Broecker WS, Peng TH (1987) The role of CaCO3 compensation in the glacial to interglacial atmospheric CO2 change. Glob Biogeochem Cycles 1:15-29

Broecker W, Bond G, Klas M, Clark E, McManus J (1992) Origin of the northern Atlantic's Heinrich events. Clim Dyn 6(3-4):265-273

Burke M, Hsiang SM, Miguel E (2015) Global non-linear effect of temperature on economic production. Nature 527(7577):235

Burke M, Davis WM, Diffenbaugh NS (2018) Large potential reduction in economic damages under UN mitigation targets. Nature 557(7706):549

Byrne MP, O'Gorman PA (2015) The response of precipitation minus evapotranspiration to climate warming: why the "wet-get-wetter, dry-get-drier" scaling does not hold over land. J Clim 28(20):8078-8092

Caldeira K, Wickett ME (2005) Ocean model predictions of chemistry changes from carbon dioxide emissions to the atmosphere and ocean. J Geophys Res Oceans 110:C09S04. https://doi.org/10.1029/2004JC002671

Cao L, Jain A (2005) An earth system model of intermediate complexity: simulation of the role of ocean mixing parameterizations and climate change in estimated uptake for natural and bomb radiocarbon and anthropogenic CO2. J Geophys Res Oceans 110. https://doi.org/10.1029/2005jc002919

Clark PU, Shakun JD, Marcott SA, Mix AC, Eby M, Kulp S, Levermann A, Milne GA, Pfister PL, Santer BD, Schrag DP, Solomon S, Stocker TF, Strauss BH, Weaver AJ, Winkelmann R, Archer D, Bard E, Goldner A, Lambeck K, Pierrehumbert RT, Plattner GK (2016) Consequences of twenty-first-century policy for multimillennial climate and sea-level change. Nat Clim Chang 6(4):360-369

Eby M, Zickfeld K, Montenegro A, Archer D, Meissner KJ, Weaver AJ (2009) Lifetime of anthropogenic climate change: millennial time scales of potential CO2 and surface temperature perturbations. J Clim 22(10):2501-2511

Enkvist PA, Dinkel J, Lin C (2009). Impact of the financial crisis on carbon economics: version 2.1 of the global greenhouse gas abatement cost curve. McKenzie\&Company

Fairbanks RG (1989) A 17,000-year glacio-eustatic sea-level record - influence of glacial melting rates on the Younger Dryas event and deep-ocean circulation. Nature 342(6250):637-642

Ganopolski A, Brovkin V (2017) Simulation of climate, ice sheets and CO2 evolution during the last four glacial cycles with an Earth system model of intermediate complexity. Clim Past 13(12):1695-1716

Golosov M, Hassler J, Krussel P, Tsyvinski A (2014) Optimal taxes on fossil fuel in general equilibrium. Econometrica 82(1):41-88

Greenstone M, Kopits E, Wolverton A (2013) Developing a social cost of carbon for US regulatory analysis: a methodology and interpretation. Rev Environ Econ Policy 7(1):23-46

Hansen J, Nazarenko L, Ruedy R, Sato M, Willis J, Del Genio A, Koch D, Lacis A, Lo K, Menon S, Novakov T, Perlwitz J, Russell G, Schmidt GA, Tausnev N (2005) Earth's energy imbalance: confirmation and implications. Science 308(5727):1431-1435

Hansen J, Sato M, Hearty P, Ruedy R, Kelley M, Masson-Delmotte V, Russell G, Tselioudis G, Cao JJ, Rignot E, Velicogna I, Tormey B, Donovan B, Kandiano E, von Schuckmann K, Kharecha P, Legrande AN, Bauer M, Lo KW (2016) Ice melt, sea level rise and superstorms: evidence from paleoclimate data, climate modeling, and modern observations that 2 a degrees $\mathrm{C}$ global warming could be dangerous. Atmos Chem Phys 16(6):3761-3812

Hays JD, Imbrie J, Shackleton NJ (1976) Variations in the Earth's orbit: pacemaker of the ice ages. Science 194:11211132

Howard PH, Sterner T (2017) Few and not so far between: a meta-analysis of climate damage estimates. Environ Resource Econ 68(1):197-225

Hsiang S, Kopp R, Jina A, Rising J, Delgado M, Mohan S, Rasmussen DJ, Muir-Wood R, Wilson P, Oppenheimer M, Larsen K, Houser T (2017) Estimating economic damage from climate change in the United States. Science 356(6345):1362-1368

IPCC (2014). Summary for policymakers. Climate change 2014: impacts,adaptation, and vulnerability Part A: Global and Sectoral Aspects. Contribution of Working Group II to the Fifth Assessment Report of the Intergovernmental Panel on Climate Change. C. B. Field, V.R. Barros, D.J. Dokken et al. Cambridge, Cambridge University Press: 1-32.

Keith DW, Holmes G, Angelo DSt and Heidel K (2018). A process for capturing CO2 from the atmosphere. Joule.

Kopp RE, Mignone BK (2012) The U.S. Government's social cost of carbon estimates after their first two years: pathways for improvement. Economics: The Open-Access, Open-Assessment E-Journal 6:2012-15. Available at SSRN: https://doi.org/10.5018/economics-ejournal.ja.2012-15

Kopp RE, DeConto RM, Bader DA, Hay CC, Horton RM, Kulp S, Oppenheimer M, Pollard D, Strauss BH (2017) Evolving understanding of Antarctic ice-sheet physics and ambiguity in probabilistic sea-level projections. Earths Future 5(12):1217-1233 
Lawrence DM, Slater AG (2005) A projection of severe near-surface permafrost degradation during the 21st century. Geophyc Res Lett 32(L23301). https://doi.org/10.1029/2005GL025080

Liu ZH, Macpherson GL, Groves C, Martin JB, Yuan DX, Zeng SB (2018) Large and active CO2 uptake by coupled carbonate weathering. Earth Sci Rev 182:42-49

Macayeal DR (1993) Binge/purge oscillations of the Laurentide ice-sheet as a cause of the North-Atlantics Heinrich events. Paleoceanography 8(6):775-784

Milliman JD (1993) Production and accumulation of calcium carbonate in the ocean: budget of a non-steady state. Global Biogeochem Cycles 7:927-957

Minasny B, McBratney AB (2001) A rudimentary mechanistic model for soil formation and landscape development II. A two-dimensional model incorporating chemical weathering. Geoderma 103(1-2):161-179

Montgomery DR (2007) Soil erosion and agricultural sustainability. Proc Natl Acad Sci U S Am 104(33):13268-13,272

Moore FC, Diaz DB (2015) Temperature impacts on economic growth warrant stringent mitigation policy. Nature Clim Chang 5(2):127-131

Moyer EJ, Woolley MD, Matteson NJ, Glotter MJ, Weisbach DA (2014) Climate impacts on economic growth as drivers of uncertainty in the social cost of carbon. J Legal Stud 43(2):401-425

National Academies of Sciences, E., and Medicine (2017) Valuing climate damages: updating estimation of the social cost of carbon dioxide. The National Academies Press, Washington

National Geophysical Data Center (NGDC) (2006) Global digital elevation model (ETOPO2). https://www.lib. ncsu.edu/gis/esridm/2006/world_img/etopo2.html

Nordhaus WD (1982) How fast should we graze the global commons? Am Econ Rev 72(2):242-246

Nordhaus WD (2017) Revisiting the social cost of carbon. Proc Natl Acad Sci U S A 114(7):1518-1523

Paillard D (1998) The timing of Pleistocene glaciations from a simple multiple-state climate model. Nature 391:378-381

Paillard D (2001) Glacial cycles: toward a new paradigm. Rev Geophys 39:325-346

Parfit D (2017) Future people, the non-identity problem, and person-affecting principles. Philos Public Affairs 42(2):118-157

Pearce D (2003) The social cost of carbon and its policy implications. Oxford Rev Econ Policy 19(3):362-384

Porter JR, Xie L, Challinor AJ, Cochrane K, Howden SM, Iqbal MM, Lobell DB, Travasso MI (2014) Food security and food production systems. Climate change 2014: impacts, adaptation, and vulnerability. Part A: global and sectoral aspects. Contribution of Working Group II to the Fifth Assessment Report of the Intergovernmental Panel on Climate Change. C. B. [Field, V.R., Barros, D.J., Dokken, K.J., Mach, M.D., Mastrandrea, M. C., T.E. Bilir, K.L. Ebi, Y.O. Estrada, R.C. Genova, B. Girma, E.S. Kissel, A.N. Levy, S. MacCracken, and A. L. L. W. P.R. Mastrandrea. Cambridge, Cambridge University Press: 485--533.

Rahmstorf S (2007) A semi-empirical approach to projecting future sea-level rise. Science 315(5810):368-370

Ramankutty N, Evan AT, Monfreda C, Foley JA (2008) Farming the planet: 1. Geographic distribution of global agricultural lands in the year 2000. Glob Biogeochem Cycles 22(1). https://doi.org/10.1029/2007GB002952

Ramsey FP (1928) A mathematical theory of saving. Econ J 38(152):543-559

Riebesell U, Zondervan I, Rost B, Tortell PD, Zeebe RE, Morel FMM (2000) Reduced calcification of marine plankton in response to increased atmospheric CO2. Nature 407:364-367

Ritchie J, Dowlatabadi H (2017) The $1000 \mathrm{GtC}$ coal question: are cases of vastly expanded future coal combustion still plausible? Energy Econ 65:16-31

Rogner H-H (1997) An assessment of world hydrocarbon resources. Annu Rev Energy Environ 22:217-262

Rutledge D (2011) Estimating long-term world coal production with logit and probit transforms. Int J Coal Geol 85(1):23-33

Shaffer G (2009) Long time management of fossil fuel resources to limit global warming and avoid ice age onsets. Geophys Res Lett 36. https://doi.org/10.1029/2008g1036294

Sherwood SC, Huber M (2010) An adaptability limit to climate change due to heat stress. Proc Natl Acad Sci U S A 107(21):9552-9555

Socolow R, Desmond M, Aines R, Blackstock J, Bolland O, Kaarsberg T, Lewis N, Mazzotti M, Pfeffer A, Sawyer K, Siirola J, Smit B, Wilcox J (2011) Direct air capture of CO2 with chemicals. A. P. Society, American Physical Society: 100.

Stern N (2006) The stern review on the economic effects of climate change. Popul Dev Rev 32(4):793-798

https://doi.org/10.1029/GM032p0005

Tans PP (2009) An accounting of the observed increase in oceanic and atmospheric CO2 and an outlook for the future. Oceanography 22:26-36

Tol RSJ (2016) The impacts of climate change according to the IPCC. Climate Change Economics 7. https://doi. org/10.1142/s2010007816400042

Walker JCG, Kasting JF (1992) Effects of fuel and forest conservation on future levels of atmospheric carbon dioxide. Paleogeogr Palaeoclimatol Palaeoecol (Glob Planet Chang Sect) 97:151-189

Walker JCG, Hays PB, Kasting JF (1981) A negative feedback mechanism for the long-term stabilization of Earth's surface temperature. J Geophys Res 86:9776-9782 
Weitzman ML (2009) On modeling and interpreting the economics of catastrophic climate change. Rev Econ Stat 91(1):1-19

Zachos JC, Pagani M, Sloan L, Thomas E, Billups K (2001) Trends, rhythms, and abberations in global climate $65 \mathrm{Ma}$ to present. Science 292:686-693

Zimov NS, Zimov SA, Zimova AE, Zimova GM, Chuprynin VI, Chapin FS (2009) Carbon storage in permafrost and soils of the mammoth tundra-steppebiome: role in the global carbon budget. Geophys Res Lett 36: L02502. https://doi.org/10.1029/2008GL036332

Publisher's note Springer Nature remains neutral with regard to jurisdictional claims in published maps and institutional affiliations. 